\title{
Application of waste treatment sludge from water treatment in brick production
}

\author{
Ainul Haezah Noruzman ${ }^{1}$, Norhayati Palil ${ }^{1}$, Rosnani Ahmad ${ }^{1}$, Khairul Salleh Baharudin ${ }^{2}$ \\ ${ }^{1}$ Politeknik Sultan Salahuddin Abdul Aziz Shah, Selangor, Malaysia \\ ${ }^{2}$ Mahsa University, Selangor, Malaysia
}

\begin{tabular}{l} 
Article Info \\
\hline Article history: \\
Received Sep 9th, 2020 \\
Revised Oct 2th, 2020 \\
Accepted Oct 21th, 2020 \\
\end{tabular}

\section{Keyword:}

Sludge

Compressive strength

Brick

Waste

Treatment

Water

\begin{abstract}
The aim of the study is to investigate the potential use of water treatment sludge in brick properties as building material. The sludge was collected from water treatment plant and the percentages used in the mixes were $3 \%, 5 \%, 7 \%$, $10 \% 15 \%, 20 \%, 40 \%$, and $60 \%$ by weight of sand in brick. The specimen without sludge was prepared for comparison. The testing involved chemical analysis of sludges using energy dispersive X-ray fluorescence (ED-XRF) technique. Testing of compressive strength was done for hardened state properties. The samples were cured at 7 and 28 days, and the average of three samples of brick samples was measured. The results revealed that the waste sludges had higher components of $\mathrm{Zn}, \mathrm{Cu}, \mathrm{Pb}$, and $\mathrm{As}$, which was trace element concentrations in the dry sludge samples. Comparisons in terms of strength were made from the control and brick containing sludge specimens. It was observed that sludge in brick performed better when mixed with $5 \%$ as partial replacement of sand. However, the more the addition of percentages of sludge in brick, the lesser the strength observed. It can be concluded that waste treatment sludge as a result from the process of water treatment can be utilized as partial replacement of sand in brick production.
\end{abstract}

(C) 2020 The Authors. Published by IICET

This is an open access article under the CC BY-NC-SA license

(https://creativecommons.org/licenses/by-nc-sa/4.0

\section{Corresponding Author:}

Ainul Haezah Noruzman,

Politeknik Sultan Salahuddin Abdul Aziz Shah, Selangor, Malaysia

Email: ainulhaezah@yahoo.com

\section{Introduction}

Brick is one of building construction materials ever produced and used by mankind. It is accounted for about $50-80 \%$ of the total values of construction, and brick is mostly used as walling material, which plays a major role in the creation and renovation of built environment (Abdullah, and Omar, 2007). The worldwide annual production of bricks is currently about 1391 billion units, and the demand of bricks is expected to be continuously rising (Zhang, 2013). There are a few types of bricks, which are clay, sand cement, and lime sand that are normally used in construction. Conventional bricks are produced from clay with high temperature kiln firing including from ordinary Portland cement concrete. Both types of bricks consume a lot of energy and generate high volume of wastes due to quarrying operations, as well as release a large quantity of greenhouse gasses annually. 
In order to reduce the impact of waste generation, many researchers have attempted to utilize waste materials to produce bricks for environmental protection and sustainable development. A wide variety of waste materials has been studied, including waste treatment sludge from the treatment of water to produce drinking water. The increase for water demand from the industrial sector and population leads to the increased generation of waste treatment sludge. For instance, Selangor is the richest state in Malaysia that produces clean water, which is estimated about 4476 million litres per day (Selangor Water Works, 2020). On the other hand, it also contributes towards major economic sectors, especially the construction industry (24.5\%), followed by Johor (16.5\%), Kuala Lumpur (15.8\%), Sarawak (8.6\%), and Penang (6.4\%) (Bada, 2018), which makes Selangor the main national economic driver towards GDP Malaysia. Due to the large production of clean water in Selangor, excessive residuals have been produced. However, it is estimated that over 2.0 million tons of water treatment sludge are produced annually by water operators across Malaysia. Due to the cost of finding new landfill (scarcity land) and the need for sustainable best practices, sludge disposal has become a global problem, and it is necessary to look for alternative reuse of sludge (Breesem et al., 2014).

Water treatment plants produce a wide variety of waste products as well as safe drinking water. These residuals may be organic and inorganic in liquid, solid, and gaseous forms depending on the source of raw water and the types of treatment processes including coagulation/filtration, precipitative softening plant, membrane separation, ion exchange and granular activated carbon (Robinson, and Witko, 1991). One of the most common methods employed to remove suspended particles and colloids from raw water is the addition of metal salts to initiate a coagulation-flocculation process. Alum sludge is a by-product of the treatment plants that use aluminium salt as coagulant. The treatment uses coagulants, such as aluminium sulphate or also known as alum, iron-based salts ferric chloride, and ferric sulphate, which are the resultants of chemical reaction of $\mathrm{Al}$ and $\mathrm{Fe}$ salts in alkaline conditions to form hydroxide precipitates that remove impurities via coprecipitation, sorption, flocculation, and settling (Dassanayake et al., 2015; Turner et al., 2019).

Therefore, it has become important to find alternative practices to decrease the requirement needed to produce innovative building materials due to the increase of waste generation of these materials. Waste treatment sludge is a hazardous waste produced from purifying water, which has been identified as a potential alternative ingredient in making bricks. Water treatment sludge has the potential to be used as bricks in many aspects of studies in terms of strength and durability as well as different methods used to produce bricks from waste materials (Hegazy et al., 2012; Keerthana et al., 2019; Rahman et al., 2019; Sheikh et al., 2017). However, little is known regarding the utilization of water treatment sludge as partial replacement of fine aggregate in sand cement brick. This study is aimed to investigate the possible percentages of sludge to be used in sand cement brick, and to determine the compressive strength at 7 and 28 days. All samples were casted using standard normal sizes of bricks and were treated in wet curing. It is concluded that the addition of water treatment sludge as partial replacement of fine aggregate in producing sand cement brick improves in terms of strength. Furthermore, it is necessary to find out different ways for the management of sludge in order to minimise or reduce the environmental impacts associated from waste generation.

\section{Method}

\section{Cement}

Ordinary Portland Cement (OPC) complying with BS EN 197-1: 2011 was used in all mortar mixes. The chemical composition of the cement is as shown in Table 1. The determination of major and trace element present in cement based composites followed the validation of EDXRF procedure by Mijatović et al. (2019). It was observed that high percentages of $\mathrm{Ca}$ in cement samples were due to the presence of limestone $(\mathrm{CaCO} 3)$ used as raw material in cement production.

Table $1<$ Concentration of Elements with EDXRF Analysis>

\begin{tabular}{lc}
\hline Major Element & Portland Cement (\%) \\
\hline $\mathrm{Si}$ & 2.1 \\
$\mathrm{Al}$ & 0.497 \\
$\mathrm{Fe}$ & 2.476 \\
$\mathrm{Ca}$ & 49.01 \\
$\mathrm{Mg}$ & 0.201 \\
$\mathrm{~S}$ & 0.496 \\
$\mathrm{~K}$ & 0.384 \\
$\mathrm{Ti}$ & 0.123 \\
$\mathrm{P}$ & -
\end{tabular}




\begin{tabular}{lc}
\hline Major Element & Portland Cement (\%) \\
\hline $\mathrm{Sr}$ & - \\
Trace element & $12.1(\mathrm{ppm})$ \\
$\mathrm{Cr}$ & $447.5(\mathrm{ppm})$ \\
$\mathrm{Zn}$ & - \\
$\mathrm{Cu}$ & - \\
$\mathrm{As}$ & - \\
$\mathrm{Ni}$ & - \\
$\mathrm{Pb}$ & \\
\hline
\end{tabular}

\section{Fine aggregate}

Natural river-washed quartz sand complying with BS 882: 1992 was used as fine aggregate, respectively. The sand grading is shown in Table 2, and the fine modulus of sand is 2.10 .

Table $2<$ Grading of Fine Aggregate $>$

\begin{tabular}{|c|c|c|c|c|c|c|}
\hline $\begin{array}{l}\text { Sieve Size } \\
(\mathrm{mm})\end{array}$ & $\begin{array}{c}\text { Mass of } \\
\text { each Sieve } \\
\text { (g) }\end{array}$ & $\begin{array}{l}\text { Weight } \\
\text { Retained } \\
\text { (g) }\end{array}$ & $\begin{array}{c}\text { Net } \\
\text { Weight (g) }\end{array}$ & $\begin{array}{l}\text { Retained } \\
\text { weight }\end{array}$ & $\begin{array}{l}\text { passing } \\
\text { weight }\end{array}$ & $\begin{array}{l}\text { Cumulative } \\
\text { percentage } \\
\text { passing (\%) }\end{array}$ \\
\hline 2.36 & 488 & 513 & 25 & 25 & 475 & 95 \\
\hline 1.18 & 353 & 520 & 167 & 192 & 308 & 62 \\
\hline 0.6 & 304 & 398 & 94 & 286 & 214 & 43 \\
\hline 0.3 & 275 & 442 & 167 & 453 & 47 & 9 \\
\hline 0.15 & 258 & 298 & 40 & 493 & 7 & 1 \\
\hline Pan & 354 & 363 & 7 & 500 & 0 & 0 \\
\hline
\end{tabular}

\section{Waste treatment sludge (WTS)}

Waste sludge in dry condition as shown in Figure 1 was collected from a water purification plant at Bukit Badong, Selangor. Dewatered sludge cakes are the by-products from processing water treatment plant to provide clean water supply around the state of Selangor. The raw water is mainly sourced from surface water collected from several dams, lakes, and rivers, and treated at the nearby water treatment plant. In this study, the raw water was collected from Sungai Selangor Dam and Sungai Tinggi Dam, with a capacity of 950 million litres per day (MLD) (Selangor Water Works, 2020). Sludge produced during the coagulation and flocculation process is passed through the dewatering facility, and the dehydrated sludge is subject to land filling. The representative samples of dehydrated sludge were tested for chemical analysis using energy dispersive X-ray fluorescence (ED-XRF) technique.

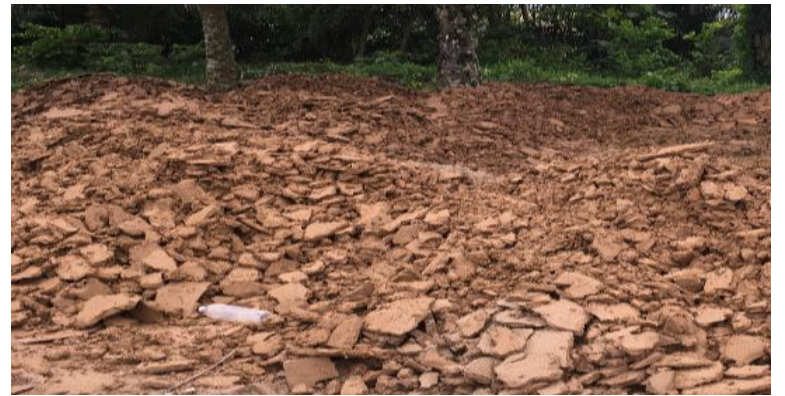

Figure 1 <Sludge Resulting from Water (River) Treatment Process>

\section{Mix Proportion}

In order to investigate the strength properties of waste sludge brick, 9 mixes were employed. The mix ratio used was 1:4. The free water to cementitious ratio was maintained constant at 0.5 for all mortar mixes. The compositions of sludge used as substitute for fine aggregate were $0 \%, 3 \%, 5 \%, 7 \%, 10 \%, 15 \%, 20 \%, 40 \%$, and $60 \%$ in cement brick as shown in Table 3. 


\begin{tabular}{lccccccccc}
\hline & \multicolumn{10}{c}{ Table $3<$ Mix Proportion of Brick> } \\
\hline Specimen & BS & BS & BS & BS & BS & BS & BS & BS & BS \\
& $0 \%$ & $3 \%$ & $5 \%$ & $7 \%$ & $10 \%$ & $15 \%$ & $20 \%$ & $40 \%$ & $60 \%$ \\
\hline $\begin{array}{l}\text { Cement } \\
\text { (g) }\end{array}$ & 258 & 258 & 258 & 258 & 258 & 258 & 258 & 258 & 258 \\
$\begin{array}{l}\text { Sand } \\
\text { (g) }\end{array}$ & 992 & 963 & 943 & 923 & 893 & 844 & 794 & 595 & 397 \\
$\begin{array}{l}\text { Water } \\
\text { (g) }\end{array}$ & 200 & 200 & 200 & 200 & 200 & 200 & 200 & 200 & 200 \\
$\begin{array}{l}\text { Sludge } \\
\text { (g) }\end{array}$ & 0 & 30 & 50 & 70 & 100 & 150 & 200 & 400 & 600 \\
\hline
\end{tabular}

\section{Compressive Strength}

The trial mix used a brick sized $102.5 \mathrm{~mm}$ x $215 \mathrm{~mm}$ x $65 \mathrm{~mm}$ for compressive strength testing. The test was carried out according to BS EN 772-1 2011 for all samples and were tested at 7 and 28 days. The average of three values was taken as the strength value for all batches.

\section{Results and Discussion}

\section{Particle Size Distribution}

The grading curves of fine aggregates are shown in Figure 2. The sand used in this study satisfied the grading requirements of fine aggregate according to BS 882:1992 which was suitable for mortar mixtures.

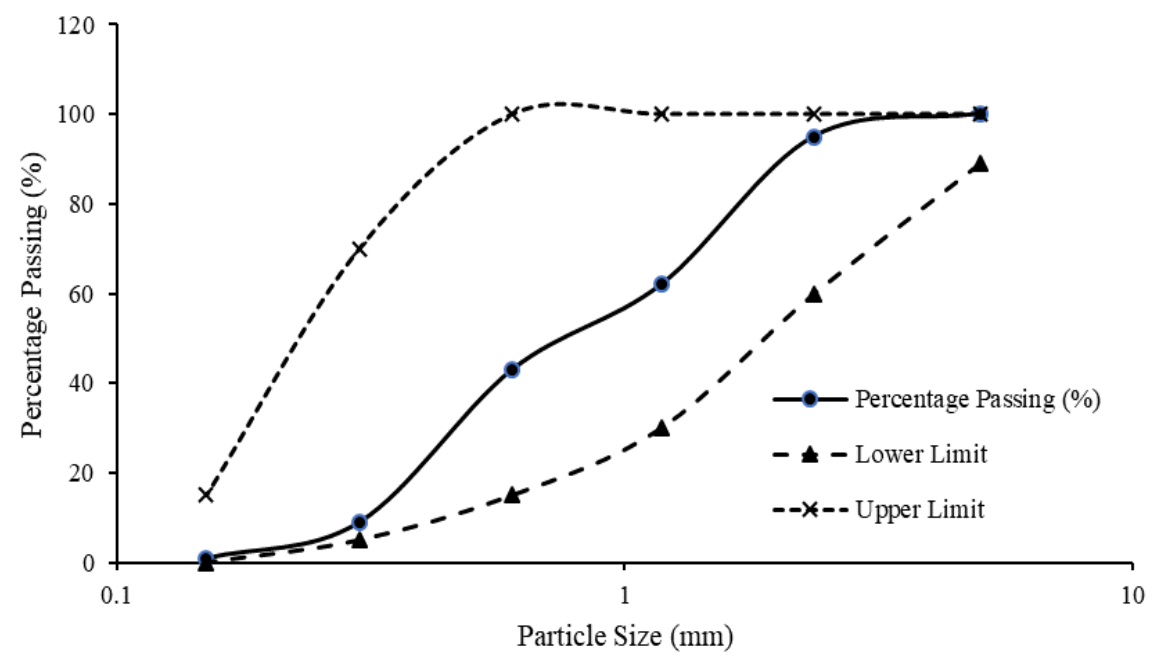

Figure $2<$ Grading Curves of Sand $>$

\section{Characteristics of water treatment sludge}

The chemical characteristics of water treatment sludge are shown in Table 4. The sludge was collected from the water treatment plant (WTP) in Bukit Badong, Selangor, and the water was treated using aluminium salt in the process of coagulation and flocculation. Major chemical compositions such as $\mathrm{Si}, \mathrm{Al}, \mathrm{Fe}$, and $\mathrm{Ca}$ were found in the sludge, and these parameters were the main components of the sludge. Other trace metals were also found in the dried sludge. The higher elemental concentrations such as $\mathrm{Zn}, \mathrm{Cu}, \mathrm{Pb}$, and $\mathrm{As}$ are the types of heavy metals which are harmful to the environment and population. Most chemical compositions and trace elements have similar characteristics with other studies (Ahmad et al., 2016).

Table $4<$ Concentration of Elements of Water Treatment Sludge with EDXRF Analysis>

\begin{tabular}{lc}
\hline Major Element & Water Treatment Sludge (\%) \\
\hline $\mathrm{Si}$ & 11.245 \\
$\mathrm{Al}$ & 6.156 \\
$\mathrm{Fe}$ & 7.484 \\
$\mathrm{Ca}$ & 0.378 \\
$\mathrm{Mg}$ & -
\end{tabular}




$\begin{array}{lc} & - \\ \mathrm{K} & 2.562 \\ \mathrm{Ti} & 0.602 \\ \mathrm{P} & 0.136 \\ \mathrm{Mn} & 468(\mathrm{ppm}) \\ \mathrm{Sr} & 52.9 \\ \mathrm{Trace} \text { element } & 134(\mathrm{ppm}) \\ \mathrm{Cr} & 642.6(\mathrm{ppm}) \\ \mathrm{Zn} & 237.1(\mathrm{ppm}) \\ \mathrm{Cu} & 244.9(\mathrm{ppm}) \\ \mathrm{As} & 20.2(\mathrm{ppm}) \\ \mathrm{Ni} & 246.5(\mathrm{ppm}) \\ \mathrm{Pb}\end{array}$

\section{Effects of Waste Sludge in Compressive Strength}

Compressive strength determines the potential of applications of the bricks. Compressive strength is usually affected by the porosity, pore size, and chemical composition of brick. It is usually defined as the failure stress measured normal to the bed face of the brick. Figure 3 illustrates the variation of compressive strength at 7 and 28 days with different percentage replacements of fine aggregate by addition of water treatment sludge in brick. It can be observed that the compressive strength of the brick decreased gradually as the percentages of water treatment sludge increased in the mixes. It was also found that the compressive strength of the mortar increased with the increase of the curing days. The specimens used mix ratio of 1:4, and the control specimens showed the compressive strength values of $7.5 \mathrm{MPa}$ and $9.3 \mathrm{MPa}$ at 7 and 28 days. From the graph, the high compressive strength was spotted at $5 \%$ replacement of sand with sludge in brick specimen. However, after adding more percentages of sludge in the brick mixes, the compressive strength values showed degradation in strength. The strength development for the mixes, for instance, strength developed at 7 curing days were 7.5 , 8.0, 5.43, 4.63, 4.13, 2.56, 1.36, and $0.47 \mathrm{MPa}$ for control mortar, and 3, 5, 7, 10, 15, 20, 40, and $60 \%$ of waste treatment sludge in brick, respectively. Similarly, at the same water cement ratio, brick mixtures were seen to develop strength of $9.67,10.37,5.7,4.77,4.77,4.3,2.57,1.63$, and $0.6 \mathrm{MPa}$ at 28 days.

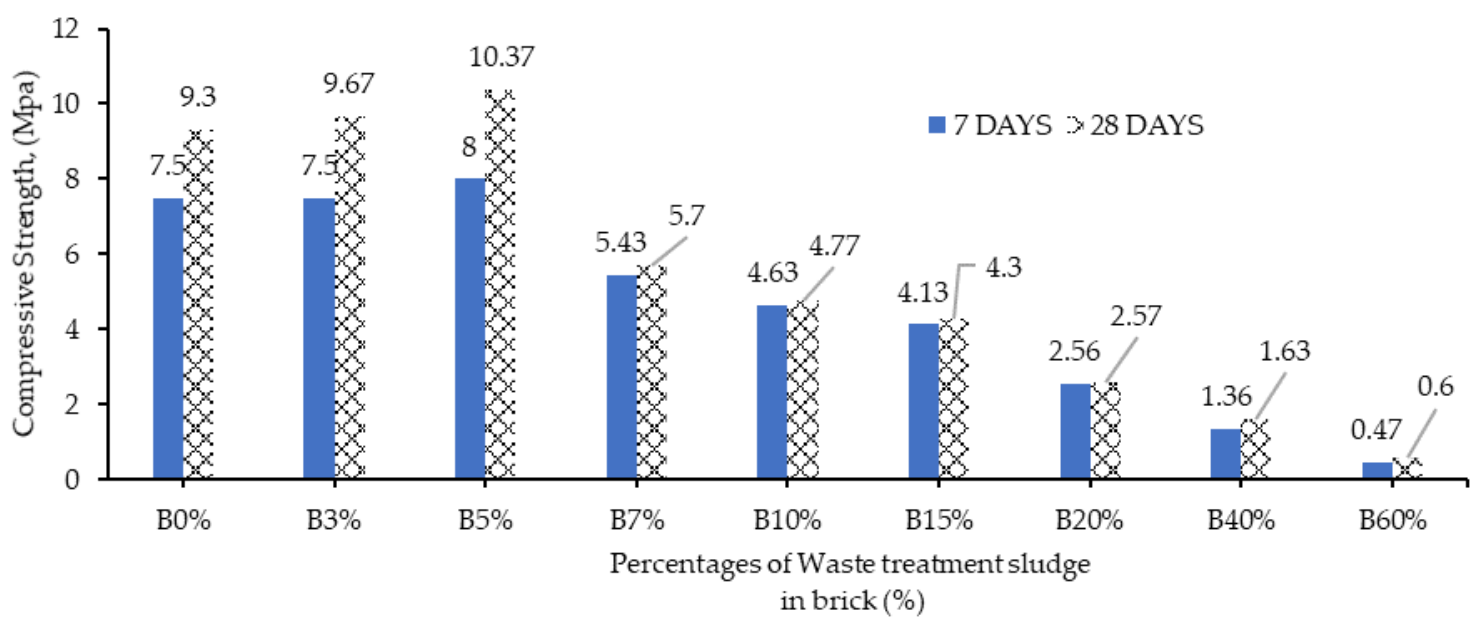

Figure $3<$ Results of Brick Sludge in Compressive Strength at 7 and 28 Days $>$

Figures 4 and 5 show the rate of strength when each percentage of brick contained water treatment compared to control brick at 7 and 28 days, respectively. It was observed that the optimum waste treatment sludge in brick was $5 \%$, and it increased the rate of strength at $7 \%$ compared to the control specimen at 7 days. However, the more the addition of WTS residual, the lower the rate of strength as shown in Figure 4, especially with $60 \%$, which was $94 \%$ decrement. On the other hand, the brick containing $5 \%$ of WTS increased in strength at 28 days which was denoted as $12 \%$ compared to the control specimen. However, the specimen showed lower rate of strength when added with $60 \%$ of WTS compared to control specimen, which promoted weaker bonding material. The contribution of strength with addition of $5 \%$ of WTS was probably caused by the presence of alum, which was used to treat water as coagulant in cement properties to promote hydration of cement in brick properties (Owaid et al., 2018). The strength results were observed to have similar 
behaviours and in line with earlier studies which used water treatment sludge in mortar properties. Higher percentages of sludge in brick caused less bonding to occur and decrease in compressive strength. These were due to the decrease of the proportion of silica content in the brick mixture, which increased the open pores between the aggregates as well as the effect of discontinuous hydration process in the matrix properties (Andrade et al., 2019).

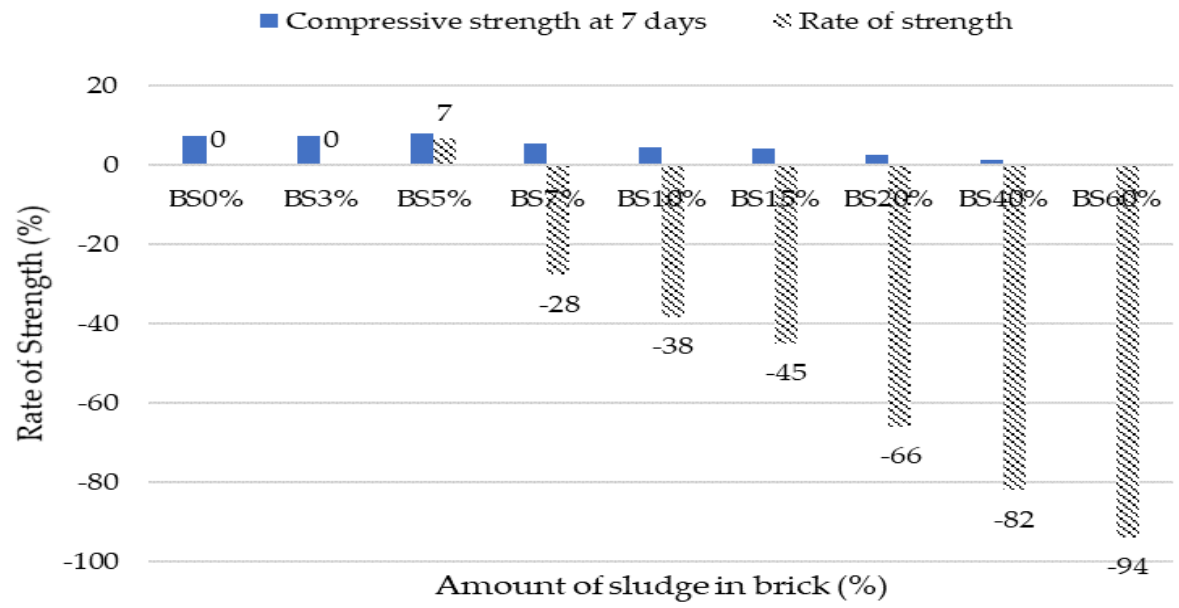

Figure $4<$ Rate of Strength of Brick Sludge Compared to Normal Brick at 7 Days $>$

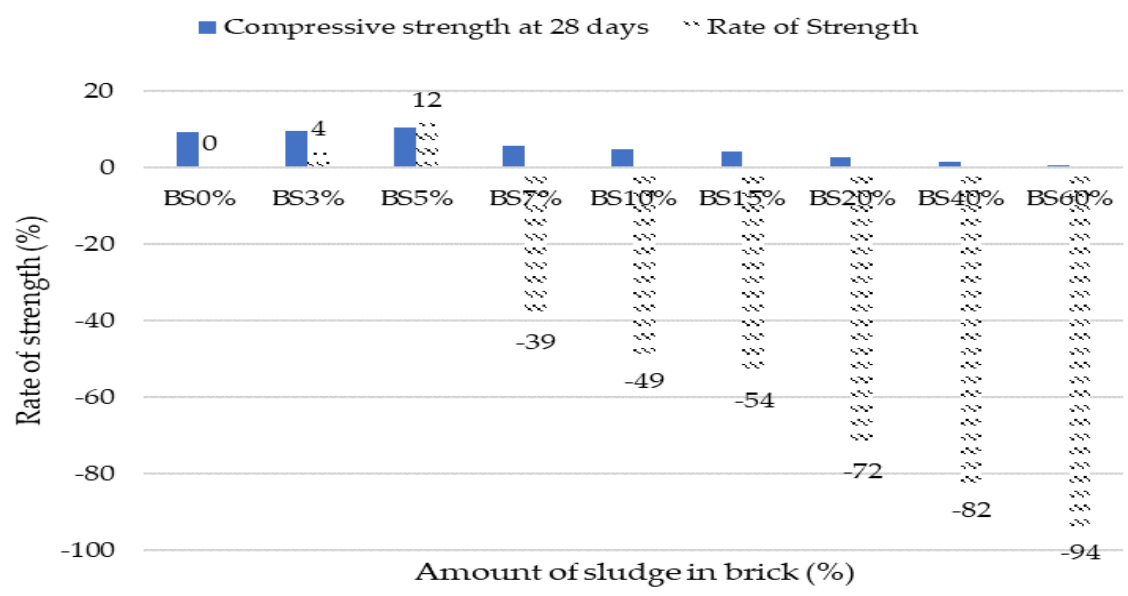

Figure $5<$ Rate of Strength of Brick Sludge Compared to Normal Brick at 28 Days $>$

\section{Effect of WTS in density of brick}

The inclusion of more percentages of residual of WTS in brick specimens showed degradation in strength compared to the control brick. However, the addition of more than $20 \%$ showed weight loss in mass of brick specimen, which consequently degraded the strength properties. The results are similar with a previous research using dry sludge water treatment sludge towards the density (Rabie et al., 2019). 


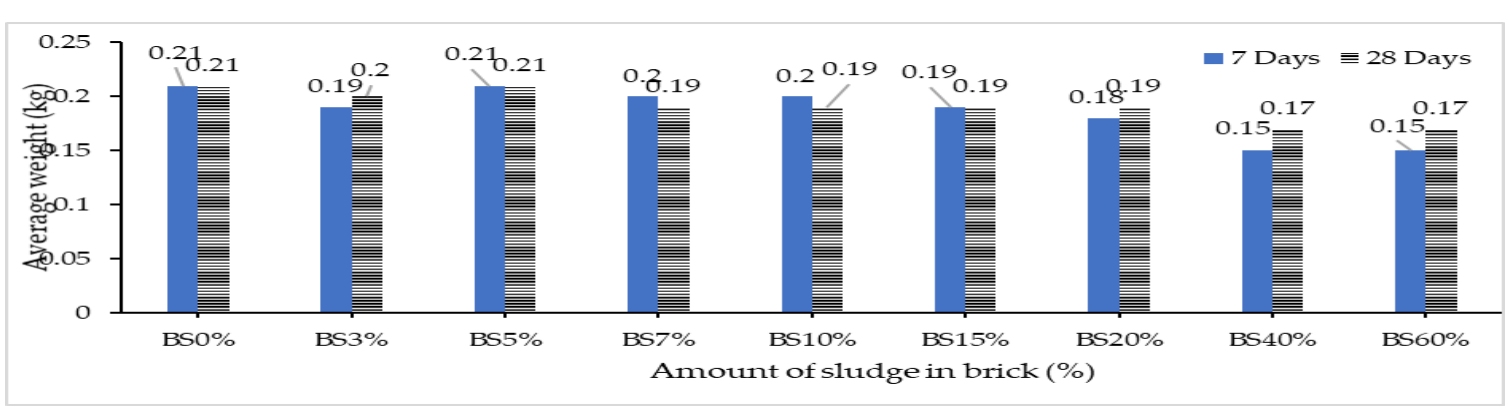

Figure $6<$ Density of Brick Containing Water Treatment Sludge $>$

\section{Conclusions}

The conclusions that can be drawn from this study are as: 1) The results show that 5\% of WTS produces an optimum performance result of strength in sand cement brick properties. 2) As the water treatment sludge replacement percentages increase, the compressive strength decreases due to possible lack of effective bonding within the particle sizes in mortar. 3) The rate of strength is lower when more than 5\% of WTS is added in sand cement brick. 4) The density of brick also reduces with high partial replacement of fine aggregate in sand cement brick.

\section{Acknowledgment}

The authors gratefully acknowledge final year project students; Nurun Najihah Nor Azli, Muhammad Shahrulazmi Hashim, Farah Hannah Mohd Zaki, and Putra Fayzul Hyshamuddin Mohd Fauziman, and staffs of the Department of Civil Engineering, Politeknik Sultan Salahuddin Abdul Aziz Shah, for support and guidance.

\section{References}

Abdullah, C. S., and Omar, W. M. S. W. (2007). The Status and Development of Malaysian Brick Industry. In Prosiding Kebangsaan Awam '07. Pusat Pengajian Kejuruteraan Awam, Universiti Sains Malaysia. (pp. 283294). https://doi.org/10.1126/science.113.2929.169

Ahmad, T., Ahmad, K., and Alam, M. (2016). Characterization of Water Treatment Plant's Sludge and its Safe Disposal Options. Procedia Environmental Sciences, 35, 950-955. https://doi.org/10.1016/j.proenv.2016.07.088

Andrade, J. J. de O., Possan, E., ChiaradiaWenzel, M., and da Silva, S. R. (2019). Feasibility of using calcined water treatment sludge in rendering mortars: A technical and sustainable approach. Sustainability (Switzerland), 11(13). https://doi.org/10.3390/su11133576

Bada, F. (2018). The Biggest Industries In Malaysia. Retrieved May 18,2020. Retrieved from https://www.worldatlas.com/articles/the-biggest-industries-in-malaysia.html

Breesem, K. M., Faris, F. G., and Abdel-Magid, I. M. (2014). Reuse of Alum Sludge in Construction Materials and Concrete. Infrastructure University Kuala Lumpur Research Journal, 2(1), 20-30.

Dassanayake, K. B., Jayasinghe, G. Y., Surapaneni, A., and Hetherington, C. (2015). A review on alum sludge reuse with special reference to agricultural applications and future challenges. Waste Management, 38(1), 321-335. https://doi.org/10.1016/j.wasman.2014.11.025

Hegazy, B. E. D. E., Fouad, H. A., and Hassanain, A. M. (2012). Brick manufacturing from water treatment sludge and rice husk ash. Australian Journal of Basic and Applied Sciences, 6(3), 453-461.

Keerthana, S., Kavya, K., Pradeep, T., and Sharmila, S. (2019). Study on effect of partial replacement of sludge in bricks. International Journal of Recent Technology and Engineering, 7(6), 364-369.

Mijatović, N., Terzić, A., Pezo, L., Miličić, L., and Živojinović, D. (2019). Validation of energy-dispersive Xray fluorescence procedure for determination of major and trace elements present in the cement based composites. Spectrochimica Acta - Part B Atomic Spectroscopy, 162, 105729. https://doi.org/10.1016/j.sab.2019.105729

Owaid, H. M., Hamid, R., Rozaimah, S., Abdullah, S., and Tan, N. (2018). Effects of alum sludge as cement partial replacement on the mechanical properties of high-performanc...., (October 2012), 65-73.

Rabie, G. M., El-Halim, H. A., and Rozaik, E. H. (2019). Influence of using dry and wet wastewater sludge in concrete mix on its physical and mechanical properties. Ain Shams Engineering Journal, 10(4), 705-712. 
https://doi.org/10.1016/j.asej.2019.07.008

Rahman, Z. A., Saleh, N. M. M., Idris, W. M. R., and Lihan, T. (2019). Thermal effect on mechanical characteristics of drinking water sludge brick incorporated with rice husk Ash (Kesan Suhu terhadap Cirian Mekanik Bata Sisa Rawatan Air Campuran Abu Sekam Padi). Sains Malaysiana, 48(11), 25412549. https://doi.org/10.17576/jsm-2019-4811-24

Robinson, M. P., and Witko, J. B. (1991). Overview of Issues and Current State-of-the Art Water Treatment Plant Waste Management Programs. In Annual Conference Proceedings. AWWA Quality for the New Decade, Philadelphia, PA. June 23-27. Retrieved from http://www.nesc.wvu.edu/pdf/dw/publications/ontap/2009_tb/water_treatment_DWFSOM49.pdf

Selangor Water Works. (2020). In Wikipedia. Retrieved May 17, 2020. Retrieved from https://en.wikipedia.org/wiki/Selangor_water_works

Sheikh Khalid, F., Shah Herman, H., Azmi, N. B., and Juki, M. I. (2017). Sand Cement Brick Containing Recycled Concrete Aggregate as Fine-Aggregate Replacement. MATEC Web of Conferences, 103. https://doi.org/10.1051/matecconf/201710301016

Turner, T., Wheeler, R., Stone, A., and Oliver, I. (2019). Potential Alternative Reuse Pathways for Water Treatment Residuals: Remaining Barriers and Questions-A Review. Water, Air, and Soil Pollution, 230(9). https://doi.org/10.1007/s11270-019-4272-0

Zhang, L. (2013). Production of bricks from waste materials - A review. Construction and Building Materials, 47, 643-655. https://doi.org/10.1016/j.conbuildmat.2013.05.043 